\title{
Gambaran Perilaku Ibu Rumah Tangga Mengenai Upaya Pencegahan DBD
}

\author{
Khoirunnisa Putri', Hardisman ${ }^{2}$, Eka Nofita ${ }^{3}$ \\ ${ }^{1}$ Fakultas Kedokteran Universitas Andalas, Padang \\ ${ }^{2}$ Bagian IImu Kesehatan Masyarakat Fakultas Kedokteran Universitas Andalas, Padang \\ ${ }^{3}$ Bagian Parasitologi Fakultas Kedokteran Universitas Andalas
}

\begin{abstract}
A B S T R A C T
Latar Belakang. Jumlah kasus DBD di kota Padang berfluktuasi dari tahun ke tahun. Pengendalian DBD yang tepat adalah dengan pengendalian vektornya melalui 4M Plus yang tidak dapat berhasil dengan baik jika tidak melibatkan peran serta masyarakat.

Objektif. Penelitian ini dilakukan untuk mengetahui tingkat pengetahuan, sikap, dan tindakan masyarakat mengenai pencegahan DBD yang diwakilkan oleh ibu rumah tangga di wilayah kerja Puskesmas Kuranji.
\end{abstract}

Metode. Penelitian ini merupakan penelitian deskriptif dengan desain penelitian cross-sectional. Pengambilan sampel menggunakan teknik random sampling. Responden penelitian adalah ibu rumah tangga. Instrumen penelitian ini adalah kuesioner yang berisi 8 item pertanyaan pengetahuan, 10 item pertanyaan sikap dan 10 item pertanyaan tindakan.

Hasil. Hasil penelitian ini menunjukkan bahwa dari total 91 responden sebagian besar memiliki tingkat pengetahuan rendah $(40,7 \%)$, sikap negatif $(54,9 \%)$ dan tindakan kurang $(38,4 \%)$ mengenai pencegahan DBD. Kebanyakan responden memiliki rentang usia 51-60 tahun $(29,7 \%)$, tingkat pendidikan SMA $(38,5 \%)$ dan pernah mendapat informasi mengenai DBD $(94,5 \%)$ yang paling banyak melalui TV $(31,9 \%)$. Hasil penelitian juga menunjukkan bahwa responden dengan sikap negatif cenderung memiliki tindakan pencegahan yang kurang baik.

Kesimpulan. Responden di wilayah Kerja Puskesmas Kuranji masih memiliki tingkat pengetahuan yang rendah, sebagian besar bersikap negatif dan lebih dari sepertiga melakukan tindakan yang kurang mengenai upaya pencegahan DBD menyebabkan masih tingginya kasus DBD.

Kata Kunci: DBD, Pengetahuan, Sikap, Tindakan

Background. The number of dengue cases in the city of Padang fluctuates from year to year. The proper control of DHF is by controlling the vector through $4 \mathrm{M}$ Plus which cannot be successful if it does not involve community participation.

Objective. This research was conducted to determine the level of knowledge, attitudes, and actions of the community regarding the prevention of DHF represented by housewives.

Method. This research was a descriptive study with a crosssectional research design. Total sampling used a random sampling technique. Research respondents were housewives.
The research instrument was a questionnaire containing 8 items of knowledge questions, 10 items of attitude questions, and 10 items of action questions.

Result. The results of this study indicate that a total of 91 respondents most of them have a low level of knowledge (40.7\%), a negative attitude (54.9\%), and lack of action (38.4\%) regarding the prevention of DHF. Most respondents have an age range of 51-60 years (29.7\%), high school education level (38.5\%), and have received the most information about DHF (94.5\%) through TV (31.9\%). The results also showed that respondents with negative attitudes tend to have bad actions of DHF prevention.

Conclusion. Respondent in Puskesmas Kuranji working areas has a low level of knowledge, negative attitude, and poor actions regarding the prevention of DBD which cause the number of dengue case still high.

Keywords: DHF, Knowledge, Attitude, Action

\section{Apa yang sudah diketahui tentang topik ini?}

Pengetahuan, Sikap dan Tindakan masyarakat mengenai PSN 4M Plus sangat penting dalam memengaruhi keberhasilan upaya pencegahan DBD.

\section{Apa yang ditambahkan pada studi ini?}

Upaya pencegahan DBD dilakukan dengan PSN (Pemberantasan Sarang Nyamuk) 4M Plus yaitu menutup, menguras, mengubur dan atau mendaur ulang serta memantau jentik-jentik nyamuk.

\section{CORRESPONDING AUTHOR \\ Name: Khoirunnisa Putri \\ Phone: +6282187304804 \\ E-mail: khoryputri@gmail.com}

\section{ARTICLE INFORMATION}

Received: September $23^{\text {rd }}, 2020$

Revised: October $15^{\text {th }}, 2020$

Available online: October $31^{\text {st }}$, 2020 


\section{Pendahuluan}

Demam berdarah dengue merupakan penyakit akibat virus Dengue dan ditularkan oleh nyamuk Aedes aegypty. Sebagian besar penyakit ini menyerang anak berumur $<15$ tahun, namun dapat juga menyerang orang dewasa. ${ }^{1}$ Virus Dengue ditemukan di Queensland, Australia Utara sejak tahun 1981.2 Di dunia, virus Dengue tersebar di seluruh daerah tropis dimana sebagian besar daerah tropis ini merupakan daerah endemis. Pola penyakit ini terus berubah yang mungkin berkaitan dengan pertumbuhan populasi yang begitu cepat, terlalu padat, dan upaya pengendalian nyamuk yang tidak tepat. ${ }^{3}$ Di Asia, virus Dengue endemis di China Selatan, Hainan, Vietnam, Laos, Kamboja, Thailand, Myanmar, India, Pakistan, Sri Lanka, Indonesia, Filipina, Malaysia dan Singapura. Sedangkan negara dengan endemisitas rendah terdapat di Papua Nugini, Bangladesh, Nepal, Taiwan dan sebagian besar negara Pasifik. ${ }^{2}$

Kejadian Luar Biasa dengue pertama kali terjadi tahun 1653 di Frech West Indies (Kepulauan Karibia), walaupun penyakitnya telah dilaporkan di Cina pada awal tahun 992 SM. Kasus DBD di Australia pertama kali dilaporkan pada tahun 1897, serta di Italia dan Taiwan tahun 1931. Kemudian pada tahun 1953-1954 terjadi KLB di Filipina, sejak saat itu serangan penyakit DBD disertai tingkat kematian yang tinggi melanda beberapa negara di wilayah Asia Tenggara termasuk Indonesia, Myanmar, Thailand, Singapura, Kamboja, Malaysia, Filipina, dan Vietnam. Dua puluh tahun kemudian, terjadi peningkatan kasus dan wilayah penyebaran DBD yang begitu hebat. Saat ini KLB muncul setiap tahunnya di beberapa negara di Asia Tenggara. ${ }^{4} \mathrm{Di}$ Indonesia penyakit ini mulai dikenal di Surabaya dan Jakarta pada tahun 1968 dan terus meluas ke seluruh Indonesia, kemudian pada tahun 2010 kasus DBD telah ada di 33 propinsi dan 440 kabupaten/kota. ${ }^{5}$

Terdapat sekitar 50 juta atau lebih kasus dengue tiap tahunnya di seluruh dunia, dengan 400.000 kasus demam berdarah dengue. ${ }^{6}$ Di Indonesia, DBD merupakan salah satu penyakit yang menjadi masalah kesehatan masyarakat dan endemis di hampir seluruh kota dan kabupaten. Penyakit ini sering menimbulkan KLB di beberapa daerah endemis DBD, yaitu daerah-daerah dengan tingkat kepadatan penduduk yang tinggi, seperti provinsi-provinsi di Pulau Jawa, Bali, dan Sumatera. Pada tahun 2010, Incidence Rate telah mencapai 65,62/100.000 penduduk dengan Case fatality rate $0,87 \% .{ }^{2}$ Provinsi Sumatera Barat merupakan provinsi dengan kasus DBD terbanyak di Pulau Sumatera. ${ }^{7}$ Pada tahun 2012-2015 kasus DBD di Sumatera Barat mengalami fluktuasi. Pada tahun 2012 terdapat 3.157 kasus, kemudian mengalami penurunan pada tahun 2013 sebanyak 2916 kasus, tahun 2014 sebanyak 2.311 kasus, dan meningkat pada tahun 2015 sebanyak 3047 kasus. ${ }^{8}$ Kota Padang adalah daerah endemis DBD di Sumatera Barat yang mempunyai jumlah kasus DBD tertinggi dan selalu ada korban jiwa setiap tahunnya. ${ }^{9}$

Pada tahun 2014-2017 jumlah kasus DBD di kota Padang berfluktuasi dari tahun ke tahun. Dinas Kesehatan Kota Padang menjelaskan bahwa terjadinya kasus DBD di Padang dipicu oleh adanya perubahan iklim dan kurangnya perilaku hidup bersih dari warga. Secara umum kejadian DBD tertinggi terjadi pada tahun 2015 dibandingkan dengan tahun 2014, 2016, dan 2017. Pada tahun 2015 jumlah kasus DBD tinggi hampir di setiap kecamatan, jika dibandingkan dengan tahun 2016 kecuali di Kecamatan Padang Barat dan Padang Timur. ${ }^{9}$ Pada tahun 2017, kasus DBD mengalami penurunan dibandingkan tahun 2016 dari 911 kasus menjadi 608 kasus. IR mengalami penurunan, namun terjadi kenaikan CFR, karena walaupun kasus menurun sebagian masyarakat masih belum paham siklus penyakit DBD, sehingga terjadi keterlambatan dari pertolongan medis, dimana kadang-kadang pasien sudah jatuh kedalam kondisi syok yaitu DSS. ${ }^{1}$

Kasus DBD terbanyak pada tahun 2017 terdapat di wilayah kerja Puskesmas Belimbing (74 kasus) kemudian diikuti oleh Puskesmas Pauh (70 kasus). ${ }^{1}$ Kemudian pada tahun 2018 kasus DBD mengalami peningkatan kembali sebanyak 699 kasus dengan kasus terbanyak pada wilayah kerja Puskesmas Belimbing (105 kasus), Puskesmas Pauh (55 kasus), dan Puskesmas Air Dingin (40 kasus) dengan angka kematian 3 orang (jumlah kematian 1 orang di masing-masing puskesmas). ${ }^{10}$ Kecamatan dengan kasus DBD paling banyak terdapat di Kecamatan Kuranji dan 
Koto Tangah. ${ }^{11}$ Berdasarkan data yang didapatkan dari laporan kasus DBD tahun 2019 oleh bagian P2P (Pengendalian dan Pemberantasan Penyakit) Dinas Kesehatan Kota Padang, Puskesmas Kuranji memiliki Incidence Rate terbesar dari seluruh puskesmas di Kota Padang yaitu sebesar 105,8/29.290 penduduk. ${ }^{12}$

Pengendalian DBD yang tepat adalah dengan memutus rantai penularan yaitu dengan pengendalian vektornya, karena vaksin dan obat masih harus diteliti. Salah satu metode untuk pengendalian vektor DBD adalah manajemen lingkungan dengan mengelola atau meniadakan habitat perkembangbiakan nyamuk yang dikenal dengan gerakan Pemberantasan Sarang Nyamuk dengan melakukan 4M plus yaitu Menutup, Menguras, Memanfaatkan kembali dan Mendaur ulang barang bekas, dan Memantau serta Plus adalah salah satunya menaburkan larvasida pada air di dalam penampungan yang sulit dibersihkan. ${ }^{13}$ Penyebaran vektor DBD sudah mencapai seluruh wilayah Indonesia, hal ini dapat terjadi akibat adanya perubahan iklim secara global, kemajuan dalam teknologi transportasi, mobilitas penduduk tinggi, urbanisasi, dan infrastruktur penyediaan air bersih yang kondusif untuk perkembangbiakan vektor DBD, serta perilaku masyarakat yang belum mendukung untuk keberhasilan upaya pengendalian. Agar dapat bersama-sama menurunkan angka kesakitan dan kematian akibat penyakit menular di Indonesia, maka dilakukan pelaksanaan program pengendalian penyakit DBD. ${ }^{2}$

Pengetahuan, sikap dan tindakan masyarakat merupakan faktor-faktor yang penting dalam mempengaruhi Incidence Rate Demam Berdarah yang sangat mungkin untuk diubah. ${ }^{14}$ Tindakan kesehatan yang buruk merupakan hasil dari pengetahuan yang buruk pada seseorang dan sikap yang tidak mendukung dari seseorang terhadap kesehatan. Pengetahuan tentang PSN merupakan faktor yang sangat penting agar dapat mewujudkan tindakan seseorang yang mendukung dalam melakukan tindakan PSN sehingga dapat mencegah terjadinya penyakit DBD. 15

DBD termasuk penyakit berbasis lingkungan, maka pengendalian vektornya tidak dapat berhasil dengan baik jika tidak melibatkan peran serta masyarakat. Kunci keberhasilan upaya pengendalian DBD salah satunya adalah dengan meningkatkan peran aktif masyarakat, maka perlu dilakukan penelitian untuk mengetahui tingkat pengetahuan, sikap, dan tindakan masyarakat mengenai pencegahan DBD yang diwakili oleh ibu rumah tangga. Ibu rumah tangga dipilih sebagai wakil dari masyarakat karena ibu rumah tangga memiliki peran penting dalam kehidupan keluarga sehari-hari terutama dalam kebersihan rumah tangga. ${ }^{2}$

Studi pendahuluan untuk validasi kuesioner penulis lakukan di Kelurahan Kuranji yang merupakan wilayah kerja Puskesmas Belimbing pada tanggal 3 Februari 2020 dengan total 10 orang. Didapatkan $70 \%$ ibu rumah tangga memiliki tingkat pengetahuan tentang upaya pencegahan DBD yang tinggi. Sedangkan pada sikap, didapatkan keseluruhan ibu rumah tangga memiliki sikap positif dan pada tindakan didapatkan $70 \%$ ibu rumah tangga memiliki tindakan yang baik. Berdasarkan uraian diatas, peneliti tertarik untuk melakukan penelitian berupa pengetahuan, sikap, dan tindakan upaya pencegahan DBD ibu rumah tangga di wilayah kerja Puskesmas Kuranji.

\section{Metode}

Jenis penelitian ini adalah penelitian deskriptif dengan pendekatan cross-sectional yang berarti semua variabel yang diteliti hanya diukur satu kali pada satu waktu dengan tujuan memberikan gambaran mengenai pengetahuan, sikap, dan tindakan upaya pencegahan DBD ibu rumah tangga di Wilayah Kerja Puskesmas Kuranji.

Populasi penelitian ini adalah ibu rumah tangga yang berada di wilayah kerja Puskesmas Kuranji yang terdiri dari 2 kelurahan dengan jumlah populasi sebanyak 29.782 orang. Dalam penelitian ini didapatkan total sampel keseluruhan untuk sebanyak 91 orang. Pengambilan sampel untuk penelitian ini dengan menggunakan teknik Probability Sampling dengan metode proporsional random sampling.

Analisis data dilakukan secara univariat. Analisis univariat dilakukan untuk menggambarkan karakteristik responden dan distribusi skor pengetahuan, sikap dan tindakan ibu rumah tangga mengenai upaya pencegahan DBD dengan 4M Plus. 


\section{Hasil}

Penelitian ini bertujuan untuk mengetahui gamabran tingkat pengetahuan, sikap dan tindakan di wilayah kerja Puskesmas Kuranji. Penelitian dilakukan di 2 kelurahan di wilayah kerja puskesmas Kuranji pada bulan MaretAgustus 2020.

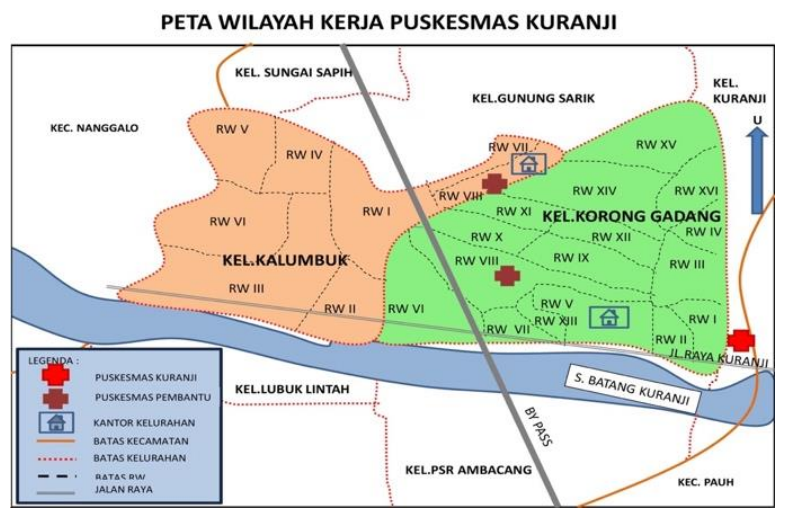

Gambar 1 Lokasi Penelitian

(sumber : Laporan Tahunan Puskesmas Kuranji Tahun 2014)16

\section{Gambaran Tingkat Pengetahuan Responden}

Pada penelitian ini didapatkan 37 (40,7\%) orang ibu rumah tangga memiliki tingkat pengetahuan rendah, 35 (38,5\%) orang ibu rumah tangga memiliki tingkat pengetahuan sedang dan $19(20,9 \%)$ orang ibu rumah tangga memiliki tingkat pengetahuan tinggi.

Tingkat pengetahuan responden di Kelurahan Korong Gadang memiliki tingkat pengetahuan sedang sebesar $30(50,8 \%)$ orang ibu rumah tangga, $15(25,4 \%)$ orang ibu rumah tangga memiliki tingkat pengetahuan tinggi dan tingkat pengetahuan rendah sebesar $14(23,7 \%)$ orang ibu rumah tangga.

Tingkat pengetahuan responden di Kelurahan Kalumbuk memiliki tingkat pengetahuan rendah sebesar $23(71,9 \%)$ orang ibu rumah tangga, 5 $(15,6 \%)$ orang ibu rumah tangga memiliki pengetahuan sedang dan $4(12,5 \%)$ orang ibu rumah tangga memiliki tingkat pengetahuan tinggi.

Tabel 1. Distribusi Tingkat Pengetahuan Responden Tentang 4M Plus

\begin{tabular}{cccc}
\hline $\begin{array}{c}\text { Tingkat } \\
\text { Pengetahuan } \\
\text { 4M Plus }\end{array}$ & $\begin{array}{c}\text { Korong } \\
\text { Gadang f f } \\
(\mathbf{\%})\end{array}$ & $\begin{array}{c}\text { Kalumbuk f } \\
\mathbf{( \% )}\end{array}$ & $\begin{array}{c}\text { Total } \\
\mathbf{f}(\mathbf{\%})\end{array}$ \\
\hline Tinggi $(76-100 \%)$ & $15(25,4)$ & $4(12,5)$ & $19(20,9)$ \\
Sedang $(60-75 \%)$ & $30(50,8)$ & $5(15,6)$ & $35(38,5)$ \\
\hline
\end{tabular}

\begin{tabular}{cccc}
\hline Rendah $(<60 \%)$ & $14(23,7)$ & $23(71,9)$ & $37(40,7)$ \\
\hline Total & $\mathbf{5 9}$ & $\mathbf{3 2}$ & $\mathbf{1 0 0}$ \\
\hline
\end{tabular}

\subsection{Gambaran Tingkat Pengetahuan \\ Responden yang Pernah Mendapatkan Informasi DBD}

Pada penelitian ini didapatkan dari total 91 responden terdapat $94,5 \%$ orang yang pernah mendapatkan informasi mengenai DBD dimana diantara responden tersebut tingkat pengetahuan rendah sebesar 38,4\%, tingkat pengetahuan sedang $36,2 \%$ dan tingkat pengetahuan tinggi sebesar 19,7\%. Responden yang tidak pernah mendapatkan informasi sebanyak 5,4\% dimana diantara responden tersebut memiliki tingkat pengetahuan rendah sebesar 2,1\%, tingkat pengetahuan sedang sebesar $2,1 \%$, dan tingkat pengetahuan tinggi sebesar $1 \%$.

\subsection{Gambaran Tingkat Pengetahuan Responden Berdasarkan Tingkat Pendidikan}

Pada penelitian ini didapatkan responden diseluruh tingkat pendidikan banyak yang memiliki tingkat pengetahuan rendah sebanyak 37 orang. Responden dengan tingkat pengetahuan tinggi memiliki persentase paling rendah $(20,8 \%)$ dibandingkan tingkat pengetahuan sedang dan rendah $(38,4 \%$ dan $40,6 \%)$.

\section{Gambaran Sikap Responden}

Pada penelitian ini sebanyak $41(45,1 \%)$ orang ibu rumah tangga memiliki sikap yang positif dan $50(54,9 \%)$ orang ibu rumah tangga memiliki sikap negatif. Pada Kelurahan Korong Gadang sebanyak $37(62,7 \%)$ orang ibu rumah tangga memiliki sikap yang positif dan $22(37,3 \%)$ orang ibu rumah tangga memiliki sikap negatif. Pada Kelurahan Kalumbuk sebanyak 4 (6,8\%) orang ibu rumah tangga memiliki sikap yang positif dan 28 $(47,5 \%)$ orang ibu rumah tangga memiliki sikap negatif.

Tabel 2. Distribusi Sikap Responden Tentang 4M Plus

\begin{tabular}{lccc}
\hline Sikap 4M Plus & $\begin{array}{c}\text { Korong } \\
\text { Gadang } \\
\mathbf{f ( \% )}\end{array}$ & $\begin{array}{c}\text { Kalumbuk } \\
\mathbf{f ( \% )}\end{array}$ & $\begin{array}{c}\text { Total } \\
\mathbf{f ( \% )}\end{array}$ \\
\hline $\begin{array}{l}\text { Positif (skor T } \\
\begin{array}{l}\text { mean) } \\
\text { Negatif (skor T }\end{array}\end{array}$ & $37(62,7)$ & $4(6,8)$ & $\begin{array}{c}41 \\
(45,1) \\
<\text { mean) }\end{array}$ \\
\hline \multicolumn{1}{c}{ Total } & $\mathbf{5 9}$ & $28(47,5)$ & $\begin{array}{c}50 \\
(54,9)\end{array}$ \\
\hline & & $\mathbf{3 2}$ & $\mathbf{1 0 0}$ \\
\hline
\end{tabular}




\subsection{Gambaran Sikap Responden Berdasarkan Tingkat Pengetahuan}

Pada penelitian ini didapatkan dari seluruh tingkat pengetahuan kebanyakan responden memiliki sikap yang negatif (54,9\%). Responden dengan tingkat pengetahuan tinggi menunjukkan sikap positif sebesar 9,8\% dan sikap negatif sebesar $10,9 \%$.

\section{Gambaran Tindakan Responden}

Pada penelitian ini sebanyak $35(38,4 \%)$ orang ibu rumah tangga memiliki tindakan yang kurang, $29(31,8 \%)$ orang ibu rumah tangga memiliki tindakan cukup dan $27(29,6 \%)$ orang ibu rumah tangga memiliki tindakan baik. Pada Kelurahan Korong Gadang sebanyak $26(28,6 \%)$ orang ibu rumah tangga memiliki tindakan baik, 20 (22,0\%) orang ibu rumah tangga memiliki tindakan yang kurang dan $13(14,3 \%)$ orang ibu rumah tangga memiliki tindakan cukup. Kelurahan Kalumbuk menunjukkan bahwa sebanyak $16(17,6 \%)$ orang ibu rumah tangga memiliki tindakan cukup, 15 $(16,5 \%)$ orang ibu rumah tangga memiliki tindakan yang kurang dan $1(1,1 \%)$ orang ibu rumah tangga memiliki tindakan baik.

Tabel 3. Distribusi Tindakan Responden Tentang 4M Plus

\begin{tabular}{cccc}
\hline $\begin{array}{c}\text { Tindakan 4M } \\
\text { Plus }\end{array}$ & $\begin{array}{c}\text { Korong Gadang Kalumbuk } \\
\text { f (\%) }\end{array}$ & $\begin{array}{c}\text { Total } \\
\mathbf{f ( \% )}\end{array}$ & $\mathbf{f ( \% )}$ \\
\hline Baik (76-100\%) & $26(28,6)$ & $1(1,1)$ & $27(29,6)$ \\
Cukup(60-75\%) & $13(14,3)$ & $16(17,6)$ & $29(31,8)$ \\
Kurang $(<60 \%)$ & $20(22,0)$ & $15(16,5)$ & $35(38,4)$ \\
\hline Total & $\mathbf{5 9}$ & $\mathbf{3 2}$ & $\mathbf{1 0 0}$ \\
\hline
\end{tabular}

\subsection{Gambaran Tindakan Responden Berdasarkan Tingkat Pengetahuan}

Pada penelitian ini responden dari seluruh tingkat pengetahuan kebanyakan memiliki tindakan pencegahan DBD yang kurang $(38,4 \%)$, sedangkan tindakan yang baik hanya $29,6 \%$. Responden dengan tingkat pengetahuan tinggi yang memiliki tindakan baik hanya 5,4\%.
Tabel 4. Gambaran Tindakan Responden Berdasarkan Tingkat Pengetahuan

\begin{tabular}{ccccc}
\hline Tingkat & \multicolumn{3}{c}{ Tindakan } & Total \\
\cline { 2 - 4 } Pengetahuan & $\begin{array}{c}\text { Baik } \\
\mathbf{f ( \% )}\end{array}$ & $\begin{array}{c}\text { Cukup } \\
\mathbf{f ( \% )}\end{array}$ & $\begin{array}{c}\text { Kurang } \\
\mathbf{f ( \% )}\end{array}$ \\
\hline Tinggi & $5(5,4)$ & $2(1)$ & $12(13,1)$ & $19(20,8)$ \\
Sedang & $11(12)$ & $9(9,8)$ & $15(16,4)$ & $35(38,4)$ \\
Rendah & $11(12)$ & $18(19,7)$ & $8(8,7)$ & $37(40,6)$ \\
\hline Total & $\mathbf{2 7 ( 2 9 , 6 )}$ & $\mathbf{2 9 ( 3 1 , 8 )}$ & $\mathbf{3 5 ( 3 8 , 4 )}$ & $\mathbf{9 1 ( 1 0 0 )}$ \\
\hline
\end{tabular}

\subsection{Gambaran Tindakan Responden Berdasarkan Sikap}

Pada penelitian ini sebagian besar responden dengan sikap positif memiliki tindakan yang baik $(20,8 \%)$, sedangkan responden dengan sikap negatif kebanyakan memiliki tindakan yang kurang (25,2\%). Responden dengan tindakan pencegahan DBD yang baik hanya $(8,7 \%)$ yang memiliki sikap negatif.

Tabel 5. Gambaran Tindakan Responden Berdasarkan Sikap

\begin{tabular}{lcccc}
\hline Sikap & \multicolumn{3}{c}{ Tindakan } & $\begin{array}{c}\text { Total } \\
\text { f (\%) }\end{array}$ \\
\cline { 2 - 4 } & $\begin{array}{c}\text { Baik } \\
\text { f (\%) }\end{array}$ & $\begin{array}{c}\text { Cukup } \\
\text { f(\%) }\end{array}$ & $\begin{array}{c}\text { Kurang } \\
\text { f (\%) }\end{array}$ & \\
\hline Positif & $19(20,8)$ & $10(10,9)$ & $11(12)$ & $41(45)$ \\
Negatif & $8(8,7)$ & $19(20,8)$ & $23(25,2)$ & $35(38,4)$ \\
\hline Total & $\mathbf{2 7 ( 2 9 , 6 )}$ & $\mathbf{2 9 ( 3 1 , 8 )}$ & $\mathbf{3 5 ( 3 8 , 4 )}$ & $\mathbf{9 1 ( 1 0 0 )}$ \\
\hline
\end{tabular}

\section{Pembahasan}

\section{Gambaran Tingkat Pengetahuan Responden}

Hasil pada penelitian ini menunjukkan bahwa tingkat pengetahuan ibu rumah tangga di wilayah kerja Puskesmas Kuranji mengenai upaya pencegahan DBD sebagian besar memiliki tingkat pengetahuan rendah sebesar 37 orang $(40,7 \%)$, tingkat pengetahuan sedang sebesar 35 orang $(38,5 \%)$ dan tingkat pengetahuan tinggi sebesar 19 orang $(20,9 \%)$. Lokasi penelitian memiliki karakteristik yang berbeda dimana perumahan responden di Kelurahan Korong Gadang masih memiliki suasana seperti rumah di perkampungan dan terdapat sungai yang cukup besar di belakang rumah warga yang masih sering dijadikan tempat pembuangan sampah, sedangkan lingkungan tempat tinggal responden di Kelurahan Kalumbuk memiliki suasana seperti perumahan pada perkotaan dan lingkungan perumahannya pun lebih bersih dan pengelolaan sampah di lingkungan lebih teratur.

Responden Kelurahan Korong Gadang memiliki tingkat pengetahuan sedang sebanyak 
$30(50,8 \%)$ orang ibu rumah tangga, $15(25,4 \%)$ orang ibu rumah tangga memiliki tingkat pengetahuan tinggi, dan $14(23,7 \%)$ orang ibu rumah tangga memiliki tingkat pengetahuan rendah, sedangkan Kelurahan Kalumbuk memiliki tingkat pengetahuan rendah sebesar $23(71,9 \%)$ orang ibu rumah tangga, $5(15,6 \%)$ orang ibu rumah tangga memiliki tingkat pengetahuan sedang dan tingkat pengetahuan tinggi sebanyak 4 $(12,5 \%)$ orang ibu rumah tangga. Tingkat pengetahuan responden Korong Gadang paling banyak adalah tingkat pengetahuan sedang sedangkan di Kalumbuk paling banyak memiliki tingkat pengetahuan rendah, adanya perbedaan ini dapat disebabkan karena tingkat pendidikan responden Korong Gadang paling banyak setingkat sarjana sedangkan di Kalumbuk paling banyak tingkat pendidikan SMA. Tingkat pengetahuan yang masih rendah dapat diakibatkan karena masih kurangnya kepedulian ibu rumah tangga dalam memerhatikan pencegahan DBD yang ada di lingkungannya.

Menurut Notoatmodjo pengetahuan adalah hasil dari pengamatan seseorang setelah melakukan penginderaan terhadap suatu objek. ${ }^{17}$ Faktor-faktor yang dapat mempengaruhi pengetahuan seseorang antara lain adalah pendidikan, pekerjaan, umur, minat, pengalaman dan informasi. ${ }^{18}$ Hasil penelitian ini sejalan dengan penelitian yang dilakukan oleh Ika (2011) memperlihatkan hasil yang tidak jauh berbeda dari penelitian yang peneliti lakukan yaitu banyak responden memiliki tingkat pengetahuan rendah sebanyak $35(39,3 \%)$ orang, dimana diantara 35 responden dengan pengetahuan buruk atau rendah terdapat sebanyak $2(2,2 \%)$ responden yang memiliki upaya pencegahan DBD yang baik, $12(13,5 \%)$ responden dengan upaya pencegahan sedang dan $21 \quad(23,6 \%)$ responden dengan pencegahan DBD yang buruk. ${ }^{19}$

Berdasarkan analisa data, responden yang pernah mendapatkan informasi sebanyak 86 orang $(94,5 \%)$ dan yang tidak pernah mendapatkan informasi sebelumnya 5 orang (5,49\%). Tingkat pengetahuan responden yang pernah mendapatkan informasi kebanyakan adalah rendah $(38,4 \%)$, sedangkan yang belum kebanyakan memiliki tingkat pengetahuan sedang $(2,1 \%)$ dan rendah $(2,1 \%)$. Hal ini tidak sejalan dengan penelitian yang dilakukan oleh Wirakusuma (2016) dimana terdapat perbedaan antara tingkat pengetahuan responden yang pernah mendapatkan informasi dengan yang belum. Responden yang pernah mendapatkan informasi sebelumnya cenderung memiliki tingkat pengetahuan sedang dan tinggi $(74,4 \%$ dan $20,5 \%$ ) sedangkan responden yang belum mendapatkan informasi cenderung memiliki tingkat pengetahuan sedang dan rendah $(74,1 \%$ dan 18,5\%).14 Hal ini bisa disebabkan karena responden kurang memperhatikan penyuluhanpenyuluhan yang diberikan mengenai upaya pencegahan DBD di lingkungannya.

Responden kebanyakan memiliki tingkat pendidikan setingkat akademi sebanyak 30 $(32,9 \%)$ orang ibu rumah tangga. Responden diseluruh tingkat pendidikan kebanyakan memiliki tingkat pengetahuan rendah sebanyak 37 orang. Responden dengan tingkat pengetahuan tinggi memiliki persentase paling rendah $(20,8 \%)$ dibandingkan tingkat pengetahuan sedang dan rendah $(38,4 \%$ dan $40,6 \%)$.

\section{Gambaran Sikap Responden}

Pada penelitian ini didapatkan sejumlah 41 responden $(45.1 \%)$ yang memiliki sikap positif terhadap pencegahan demam berdarah, dan sisanya 50 responden (54,9\%) memiliki sikap negatif terhadap pencegahan DBD. Pada Kelurahan Korong Gadang sebanyak 37 (62,7\%) orang ibu rumah tangga memiliki sikap yang positif dan $22(37,3 \%)$ orang ibu rumah tangga memiliki sikap negatif, sedangkan pada Kelurahan Kalumbuk sebanyak $4(6,8 \%)$ orang ibu rumah tangga memiliki sikap yang positif dan $28(47,5 \%)$ orang ibu rumah tangga memiliki sikap negatif.

Hasil ini serupa dengan hasil yang diperoleh dari penelitian yang dilakukan oleh Diana dkk. (2015) di kabupaten Minahasa Utara, yakni didominasi dengan responden yang bersikap negatif sebesar 63 orang $(61,2 \%)$ sedangkan yang bersikap positif 40 orang $(38,8 \%)$. Pada penelitian tersebut menggunakan 103 sampel yang dipilih secara acak dengan umur responden paling banyak berumur 30-49 tahun, tingkat pendidikan yang terbanyak adalah SMA dan pekerjaan paling banyak adalah ibu rumah tangga dan tidak dibedakan status sosial ekonomi ataupun tingkat 
pendidikannya. ${ }^{20}$ Hal ini tidak jauh berbeda dengan penelitian ini yang dilakukan dengan cara pemilihan sampel yang sama yakni dengan cara acak dan tidak dibedakan anatara status sosial ataupun tingkat pendidikan responden.

Penelitian yang dilakukan Wirakusuma (2016) di wilayah kerja Puskemas Bebandem Bali didapatkan hasil yang cukup berbeda dari penelitian peneliti dan penelitian di Minahasa Utara serta di Makassar. Pada penelitian tersebut diketahui bahwa persentase responden yang sikapnya baik terhadap DBD lebih besar $(92,4 \%)$ bila dibandingkan dengan responden yang memiliki sikap negatif $(7,6 \%)$ terhadap pencegahan DBD. ${ }^{14}$

Sikap merupakan suatu kecenderungan berperilaku yang dipengaruhi oleh pikiran, perasaan dan perhatian. Salah satu faktor yang mempengaruhi sikap seseorang adalah komponen kognitif yang berisi kepercayaan seseorang mengenai suatu obyek tertentu. ${ }^{21}$

Penelitian yang dilakukan oleh peneliti mengenai tingkat pengetahuan dibagi menjadi tiga kategori yakni tinggi, sedang dan rendah, serta didapatkan hasil pada responden dengan tingkat pengetahuan tinggi didominasi dengan sikap negatif $(10,9 \%)$. Pada responden dengan tingkat pengetahuan sedang sikap responden di dominasi dengan sikap positif $(20,8 \%)$, sedangkan responden dengan pengetahuan rendah di dominasi dengan sikap negatif $(26,3 \%)$ meskipun masih terdapat 13 responden (14,2\%) yang bersikap positif diantara responden dengan tingkat pengetahuan rendah. Terdapat penelitian yang dilakukan oleh Bahtiar (2012) yang menunjukkan hasil tak jauh berbeda dengan penelitian ini yaitu sebagian besar responden memiliki sikap negatif (58,8\%), sedangkan $41,2 \%$ memiliki sikap positif. Kebanyakan tingkat pengetahuan rendah sebesar $55,9 \%$ dan tingkat pengetahuan tinggi sebesar $44,1 \% .{ }^{22}$ Jadi dapat disimpulkan bahwa diantara tingkat pengetahuan yang rendah juga terdapat responden yang bersikap positif. Pengetahuan yang tinggi atau pengetahuan yang positif belum tentu jaminan terjadinya sikap yang positif pada seseorang, karena ada hal lain yang mampu mempengaruhi seseorang dalam bersikap seperti sarana dan prasarana. ${ }^{23}$

Penelitian yang dilakukan oleh peneliti mengenai sikap responden dikategorikan menjadi positif dan negatif berdasarkan jumlah nilai yang diperoleh responden dengan menjawab sepuluh pertanyaan yang ada pada kuesioner sikap. Penilaian menggunakan skala likert dan nilai yang kurang dari nilai mean (skor $\mathrm{T}<$ mean) termasuk sikap negatif.

Genangan air dilingkungan rumah sebaiknya dibiarkan saja merupakan pernyataan yang kebanyakan responden tidak menyetujuinya (46.2\%) dan sangat tidak setuju sebesar 45,1\%, serta hanya sebagian kecil responden yang menjawab setuju $(5,5 \%)$ dan sangat setuju $(3,3 \%)$. Beberapa responden mengatakan bahwa jika ada genangan air mereka membiarkan saja karena akan hilang sendiri. Pada penelitian Silpia (2017) menunjukkan sebesar $65 \%$ responden yang terdapat jentik nyamuk di rumahnya mempunyai kebiasaan tidak membersihkan tempat penampungan air sehingga berpotensi menjadi tempat perkembangbiakan nyamuk. ${ }^{24}$ Tanaman seperti lavender selain menjadi penghias rumah juga mampu digunakan untuk mengusir nyamuk, pernyataan ini di tanggapi positif oleh sebagian besar ibu rumah tangga, sebesar $47,3 \%$ setuju dan 42,9\% sangat setuju. Pada penelitian Novy (2019) untuk tanaman pengusir nyamuk, banyak responden yang menggunakan serai karena mudah didapatkan dan dapat digunakan dari sisa memasak serupa dengan penelitian ini dimana responden lebih sering menanam serai dibandingkan lavender. ${ }^{25}$

\section{Gambaran Tindakan Responden}

Hasil analisa data tindakan responden tentang pencegahan demam berdarah dengue kebanyakan memiliki tindakan yang baik $(29,6 \%)$, cukup (31,8\%) dan kurang (38,4\%). Pada Kelurahan Korong Gadang sebanyak 26 (28,6\%) orang ibu rumah tangga memiliki tindakan baik, $13(14,3 \%)$ orang ibu rumah tangga memiliki tindakan cukup dan $20(22,0 \%)$ orang ibu rumah tangga memiliki tindakan yang kurang, sedangkan pada Kelurahan Kalumbuk sebanyak $1(1,1 \%)$ orang ibu rumah tangga memiliki tindakan baik, $16(17,6 \%)$ orang ibu rumah tangga memiliki tindakan cukup dan 15 $(16,5 \%)$ orang ibu rumah tangga memiliki tindakan yang kurang. Hasil penelitian ini serupa dengan penelitian yang di lakukan oleh Nelly dkk. (2017) yang menemukan bahwa kebanyakan responden memiliki tindakan pencegahan DBD yang kurang yaitu 50 responden (50,5\%), cukup 
sebesar 11 responden $(11,1 \%)$ dan 38 responden $(38,4 \%)$ yang memiliki tindakan keluarga baik. ${ }^{26}$

Diantara responden dengan tingkat pengetahuan tinggi terdapat perbedaan persentase antara responden yang memiliki tindakan kurang $(13,1 \%)$ dengan responden yang mempunyai tindakan baik $(5,4 \%)$, begitupun responden dengan tingkat pengetahuan sedang lebih banyak responden yang memiliki tindakan kurang $(16,4 \%)$ dibandingkan responden dengan tindakan baik (12\%). Hal ini sejalan dengan penelitian yang dilakukan oleh Rezki dan Zaira (2017) dimana responden dengan tingkat pengetahuan baik memiliki perbedaan proporsi antara responden yang memiliki tindakan pencegahan baik dengan responden yang memiliki tindakan pencegahan kurang, tetapi dalam penelitian tersebut terdapat perbedaan dimana kebanyakan responden dengan tingkat pengetahuan yang baik memiliki tindakan pencegahan baik. ${ }^{27}$

Domain yang sangat penting dalam pembentukan tindakan seseorang adalah pengetahuan ${ }^{28}$, namun hal ini tidak sesuai dengan hasil penelitian ini dimana pada tindakan pencegahan baik kebanyakan dilakukan oleh responden yang memiliki tingkat pengetahuan sedang (12\%) dan rendah (12\%), sama halnya dengan responden dengan tindakan pencegahan kurang kebanyakan dilakukan oleh responden yang memiliki tingkat pengetahuan sedang $(16,4 \%)$ dan tinggi $(13,1 \%)$. Hasil penelitian ini sejalan dengan penelitian yang dilakukan oleh Intan (2017) mengenai hubungan pengetahuan, sikap, dan perilaku masarakat tentang 3M Plus dengan kepadatan jentik nyamuk DBD di Kelurahan Kuranji Kota Padang dimana 100\% responden memiliki pengetahuan yang baik, sebesar $83,7 \%$ responden memiliki sikap yang baik atau positif dan 32,3\% memiliki tindakan yang baik, namun diantara responden yang memiliki pengetahuan dan sikap yang baik tersebut masih banyak yang ditemukan jentik nyamuk di rumahnya. ${ }^{29} \mathrm{Hal}$ ini mungkin terjadi karena sikap hanya kecenderungan untuk bertindak. Sikap belum tentu terwujud dalam tindakan karena untuk terwujudnya tindakan diperlukan faktor lain yaitu adanya fasilitas atau sarana dan prasarana. ${ }^{30}$
Perilaku manusia merupakan hasil dari segala macam pengalaman serta interaksi manusia dengan lingkungannya yang terwujud dalam bentuk pengetahuan, sikap dan tindakan. ${ }^{31}$ Benyamin Bloom (1908) membagi perilaku manusia ke dalam tiga domain, yaitu kognitif (pengetahuan), afektif (sikap) dan psikomotor (tindakan). Ketiga domain tersebut memiliki urutan dalam pembentukan perilaku baru terutama pada orang dewasa yang diawali oleh domain kognitif. Pertama-tama individu sebelumnya harus mengetahui stimulus untuk menimbulkan pengetahuan. Kemudian timbul domain afektif berupa sikap terhadap objek yang diketahuinya. Terakhir timbul respons dalam bentuk tindakan atau keterampilan (domain psikomotor), setelah objek diketahui dan disadari sepenuhnya, namun pada kenyataannya tindakan setiap individu tidak selalu didasari oleh pengetahuan dan sikap. ${ }^{32}$

\section{Simpulan}

Berdasarkan hasil penelitian ini didapatkan kesimpulan bahwa sepertiga responden memiliki tingkat pengetahuan mengenai upaya pencegahan DBD dengan 4M Plus yang masih rendah. Sebagian besar responden memiliki sikap negatif terhadap upaya pencegahan DBD. Sepertiga responden memiliki tindakan yang kurang dalam upaya pencegahan DBD dengan 4M Plus. Maka dari itu, diharapkan agar dapat meningkatkan keberhasilan upaya pencegahan DBD dengan 4M Plus Puskesmas dan seluruh sektor terkait perlu meningkatkan pengetahuan dan kepedulian masyarakat mengenai pentingnya melakukan $4 \mathrm{M}$ Plus. Sebaiknya tetap dilakukan penyuluhan secara berkala misalnya sebulan atau dua bulan sekali terkait cara-cara pencegahan DBD dengan 4M Plus untuk meningkatkan pengatahuan masyarakar yang masih rendah.

\section{Ucapan Terima Kasih}

Ucapan terima kasih penulis sampaikan kepada semua pihak yang telah turut membantu hingga selesainya penelitian ini.

\section{Daftar Pustaka}

1. Dinas Kesehatan Kota Padang. Profil kesehatan kota padang tahun 2017. Dinas Kesehatan Kota Padang. Padang; 2017. 
2. Direktorat Jenderal Pengendalian Penyakit Dan Penyehatan Lingkungan. Modul pengendalian demam berdarah dengue. Handoko D, Prasetyowati EB, Hartoyo S, editors. Jakarta; 2011.

3. Brooks FG. Mikrobiologi kedokteran jawetz, melnick, \& adelberg. edisi 25. Adityaputri A, editor. Jakarta: Penerbit Buku Kedokteran EGC; 2013. 50 p.

4. Purnama R, Garmini R. Sosialisasi Pencegahan Dan Pemberantasan Penyakit DBD (Demam Berdarah Dengue) Di Desa Mariana Banyuasin I. Suluh AbdiJurnal Ilm Pengabdi Kpd Masy. 2019;1(1):5760.

5. Tomia A, Hadi U, Soviani S, Retnani E. Kejadian Demam Berdarah Dengue (Dbd) Berdasarkan Faktor Iklim Di Kota Ternate. Media Kesehat Masy Indones Univ Hasanuddin. 2016;12(4):241-9.

6. Dhillon K, Purba J, Simanjuntak S. Gambaran Perubahan Jumlah Trombosit Pada Penderita Dewasa Demam Berdarah Dengue Yang Dirawat Di RSUD Deli Serdang Pada Tahun 2014. J Kedoteran Methodist. 2015;8:18-23.

7. Novita B. Implementasi Kebijakan Pengendalian Penyakit Demam Berdarah Dengue (DBD) di Kota Padang (Skripsi). Universitas Andalas; 2019.

8. Primadani T. Hubungan Faktor Penggerakan Pemberantasan Sarang Nyamuk Demam Berdarah Dengue Dengan Angka Bebas Jentik Di Wilayah Kerja Puskesmas Pauh Tahun 2018 (Skripsi). Univesitas Andalas; 2018.

9. Kustanto DR, Rahmi F, Fransiska M, Hadi D. Analisis Epidemiologi Penyakit Demam Berdarah Dengue Melalui Pendekatan Temporal Dan Hubungannya Dengan Faktor Iklim Kota Padang Tahun 2014-2017. J Kesehat Stikes Prima Nusant Bukittinggi. 2019;1:22-6.

10. Dinas Kesehatan Kota Padang. Profil Kesehatan Tahun 2018. Padang; 2019.

11. Dinas Kesehatan Kota Padang. Laporan Tahunan Tahun 2018. Padang; 2019.

12. Dinas Kesehatan Kota Padang. Laporan Kasus DBD Per Puskesmas DKK Padang Tahun 2019. Padang; 2019.

13. Dinas Kesehatan Aceh. Giatkan PSN dan 4M Plus untuk Berantas Demam Berdarah [Internet]. 2019 [cited 2020 Jan 21]. Available from: https://dinkes.acehprov.go.id/news/read/2019/02/ 08/244/giatkan-psn-dan-4m-plus-untuk-berantasdemam-berdarah.html

14. Wirakusuma I. Gambaran tingkat pengetahuan, sikap, dan praktik tentang pencegahan demam berdarah dengue di wilayah kerja puskesmas bebandem (Skripsi). Fakultas Kedokteran Universitas Udayana; 2016.

15. Supriyanto H. Hubungan atara pengetahuan, sikap, praktek keluarga tentang pemberantasan sarang nyamuk (PSN) dengan kejadian Demam Berdarah Dengue di wilayah kerja puskesmas Tlogosari Wetan kota Semarang (Skripsi). [Semarang]: Universitas Diponogoro; 2011.

16. Puskesmas Kuranji. Laporan Tahunan Puskesmas Kuranji. Padang; 2014.

17. Notoatmodjo S. Promosi Kesehatan, Teori \& Aplikasi, ed. revisi 2010. 2nd ed. Jakarta: Rineka Cipta; 2010. $50-55 \mathrm{p}$

18. Wardani N indah, SR DS, Masfiah S. Faktor-Faktor Yang Berhubungan Dengan Tingkat Pengetahuan Kader Kesehatam Tentang Thalassaemia Di Kecamatan Sumbang Kabupaten Banyumas. J
Kesmasindo. 2014;6(3):194-206.

19. Herminingrum IY, Maliya A. Hubungan Antara Tingkat Pengetahuan Masyarakat Tentang Penyakit DBD Dengan Upaya Pencegahan DBD Di Desa Sukorejo Musuk Boyolali. 2011;10-7.

20. Sitinjak KD, Pinontoan OR, Kaunang P. Hubungan Antara Perilaku Dengan Kejadian Demam Berdarah Dengue Dengue ( DBD ) Di Desa Kema III Kecamatan Kema Kabupaten Minahasa Utara Tahun 2015. 2015;1-7.

21. Nuryanti E. Perilaku Pemberantasan Sarang Nyamuk Di Masyarakat. KEMAS. 2013;9(1):15-23.

22. Bahtiar Y. Hubungan Pengetahuan Dan Sikap Tokoh Masyarakat Dengan Perannya Dalam Pengendalian Demam Berdarah Di Wilayah Puskesmas Kawalu Kota Tasikmalaya. Aspirator J Vector Borne Dis Stud. 2012;4(2):73-84.

23. Akhmadi A, Ridha M. Hubungan Pengetahuan, Sikap, dan Perilaku Masyarakat terhadap Demam Berdarah Dengue di Kota Banjarbaru, Kalimantan Selatan. J Buski. 2012;4(1):7-13.

24. Tarigan SRB. Hubungan Perilaku Masyarakat Dengan Keberadaan Jentik Aedes Aegypti Di Desa Sukanalu Kecamatan Barusjahe Kabupaten Karo Tahun 2017 (Skripsi). Politeknik Kesehatan Medan; 2017.

25. Djannah NN. Membangun Masyarakat Bebas Demam Berdarah Dengue (DBD) Di Kampung Gadel KEelurahan Karangpoh Surabaya (Skripsi). Universitas Islam Negeri Sunan Ampel Surabaya; 2019.

26. Susanty N, Tahlil T, Ismail N. Pengetahuan Sikap Dan Tindakan Ibu-Ibu Rumah Tangga Pada Saat Pra Bencana Wabah Penyakit Demam Berdarah Dengue Di Kota Banda Aceh. J Ilmu Kebencanaan Pascasarj Univ Syiah Kuala. 2017;4(3):105-10.

27. Putri R, Naftassa Z. Hubungan Tingkat Pendidikan dan Pengetahuan Masyarakat dengan Perilaku Pencegahan Demam Berdarah dengue di Desa Kemiri,Kecamatan Jayakerta, Karawang tahun 2016. J Fak Kedokt dan Kesehat. 2017;1(4):1-7.

28. Nurmala I, Rahman F, Nugroho A, Erlyani N, Laily N, Anhar VY. Promosi Kesehatan. Surabaya: Airlangga University Press; 2018. 44 p.

29. Ekaverta I. Hubungan Perilaku Masyarakat tentang 3M Plus dengan Kepadatan Jentik Nyamuk DBD di Kelurahan Kuranji. Universitas Andalas; 2017.

30. Agustini A. Promosi Kesehatan. Yogyakarta: Deepublish; 2019.19 p.

31. Alhamda S. Buku Ajar Sosiologi Kesehatan. Yogyakarta: Deepublish; 2015. 1 p.

32. Maulana HDJ. Promosi Kesehatan. Jakarta: EGC; 2013. 194-203 p. 